\title{
THEORETICAL AND EMPIRICAL RESEARCH ON GENDER AND LEADERSHIP
}

\author{
René Lauck \\ M.A.
}

\begin{abstract}
The aim of this article is to shed light on theoretical and empirical research on gender and leadership. The article shows that the topics leadership and gender underlie a vivid debate about differences and similarities between female and male leaders in management science. In general, women are still facing substantial barriers and thus are underrepresented in senior leadership positions. From the human capital perspective, women are at least or even better educated than their male counterparts. In fact, women do have less work experience, which can be traced back to childcare and domestic duties. Moreover, research shows that women deal with stress differently and have more problems in establishing informal networks than men. From the leadership effectiveness perspective, female leaders tend to use more participative, democratic, or transformational leadership styles and a higher individualised consideration towards employees than men do. Besides, women are more effective in leadership roles that are congruent with their gender, are more attentive to interpersonal relations, and try to establish an atmosphere of harmony compared to male managers. Furthermore, the article deals with the glass cliff effect that describes that women are more likely to be appointed to senior leadership positions under precarious financial situations than men. Moreover, studies that researched the impact of women in CEO positions affecting the financial performance offer mixed support and are partly contradicting. In addition, this article also discusses Schein's think manager-think male paradigm and Heilman's lack of fit model and offers explanations for stereotyped behaviours against women.
\end{abstract}

Keywords: gender and leadership, leadership styles, gender differences, leader personality traits, leadership role, leadership competence.

\section{Introduction}

To begin with, the topic of leadership has been part of human experience since people formed groups to cope with threats from the environment, dangerous animals, or other individuals. In particular, most discussions about leadership range from antiquity through the 1970s primarily focusing on men, with very little emphasis on women as leaders or gender and leadership. ${ }^{1}$ Now, at the beginning of the $21^{\text {st }}$ century, the

1 Eklund, K. E., Barry, E. S., Grunberg, N. E. (2017), Gender and Leadership. Intech open science open minds, pp. 129-130. 
topic of women and leadership is gaining significant attention ${ }^{2}$, which can be traced back to changing conditions in work organisations. ${ }^{3}$ Scholars started out questioning how women lead and if differences between men and women exist and referred to highly effective female leaders such as Chancellor Angela Merkel of Germany or President Dilma Rousseff of Brazil. ${ }^{4}$ Considering the employment in the USA, women are still underrepresented in leadership positions in companies, institutions of higher education, and in politics. ${ }^{5}$ In particular, the Catalyst (2019) reports that $44.7 \%$ of the total S\&P 500 labour force are women. Moreover, women account for $36 \%$ in firstor mid-level positions and only $4.8 \%$ Chief Executives Officers are female. ${ }^{67}$ The Centre for Women and Politics (2016) further highlights that women are also underrepresented in elective offices. In detail, women hold 105 seats $(19.6 \%)$ of the 535 seats in the $114^{\text {th }}$ U.S. congress and $20(20 \%)$ of the 100 seats in the Senate. In addition, in 2016 only 75 women hold state-wide elective offices in the United States of America. ${ }^{8}$ According to the business report from Grant Thornton (2016), women hold only $24 \%$ of senior roles and $33 \%$ of businesses have no women in senior management positions. ${ }^{9}$ Carli/Eagly (2011) and Paustian-Underdahl/Walker/Woehr (2014) further stress that although the proportion of women improved in the last years women did not reach parity with men $^{10}{ }^{11}$ and remain disproportionately

2 Wright, P. (2011), Women and leadership style. Group, Vol. 35, Issue 3, p. 248.

3 Yukl, G. (2013), Leadership in Organizations. England, Eighth Edition, Pearson, p. 359.

4 Hoyt, C. L., Simon, S. (2016), Gender and Leadership. In: Northouse, P. G.: Leadership. Theory and Practice. Seventh Edition, United Kingdom, Sage Publications, p. 397.

5 Chin, J. L. (2014), Women and Leadership. In: Day, D. V.: The Oxford Handbook of Leadership and Organizations. New York, Oxford University Press, pp. 733-734.

6 Catalyst (2018), Pyramid: Women in S\&P 500 companies. https://www.catalyst.org/research/women-in-sp-500-companies (accessed on 22. February 2019).

7 Warner, J., Corley, D. (2017), The Women's Leadership Gap. Women's Leadership by the Numbers. Center for American Progress, p. 1, https://cdn.americanprogress.org/content/ uploads/2017/05/21145352/WomenLeadershipGap2017-factsheet1.pdf (accessed on 22. February 2019).

8 Center for American Women and Politics (2016), Women in Elective Office 2016. http:// www.cawp.rutgers.edu/women-elective-office-2016 (accessed on 23. February 2019).

9 Grant Thornton (2016), Women in business. Turning promise into practice - Grand Thornton International Business Report 2016. https://www.grantthornton.global/globalassets/wib turning_promise into_practice.pdf (accessed on 23.February 2019).

${ }^{10}$ Carli, L. L., Eagly, A. H. (2011), Gender and Leadership. In: Bryman, A., Collinson, D., Grint, K., Jackson, B., Uhl-Bien, M. The Sage Handbook of Leadership, London, Sage Publications, pp. 103-104.

${ }^{11}$ Paustian-Underdahl, S. C., Walker, L. S., Woehr, D. J. (2014), Gender and Perceptions of Leadership Effectiveness: A Meta-Analysis of Contextual Moderators. Journal of Applied Psychology, Vol. 99, Issue 6, p. 1129. 


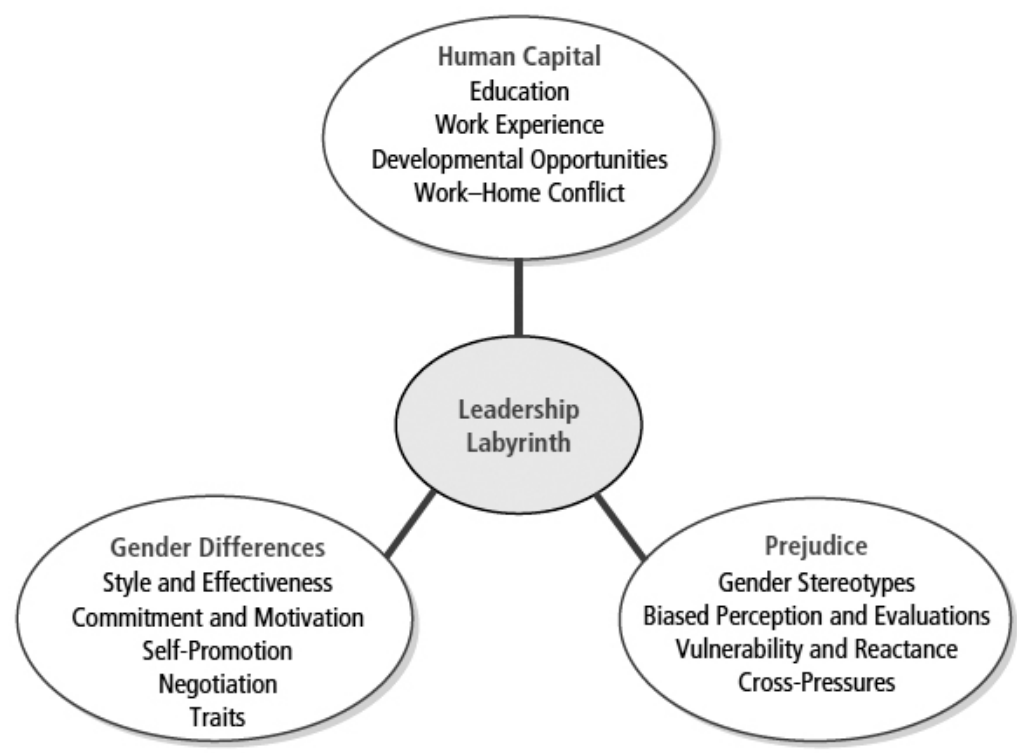

Source: Hoyt/Simon, 2016, p. 400.

Figure 1. Understanding the Leadership Labyrinth

concentrated in lower-level hierarchies. ${ }^{12}$ Thus, statistics show selection rates for leadership positions vary between men and women, both in the USA, as well as around the world. ${ }^{13}$

According to Hoyt, Simon (2016), Gipson et al. (2017) and Yukl (2013), the discussion of women's underrepresentation in high-level relationships can be traced back to three major types of explanations. Differences between men and women are based on human capital investments followed by gender differences and finally prejudice and discrimination against

${ }^{12}$ Powell, G. N., Graves, L. M. (2003), Women and Men in Management. 3rd Edition, California, Sage Publications, p. 3.

${ }^{13}$ Gipson, A. N., Pfaff, D. L., Mendelsohn, D. B., Catenacci, L. T., Burke, W. W. (2017), Women and Leadership. Selection, Development, Leadership Style, and Performance. The Journal of Applied Behavioral Science, Vol. 53, Issue 1, p. 34. 
female leaders. ${ }^{14} 1516$ The following Figure 1 illustrates and summarizes the three main types of explanations.

\section{Differences in Human Capital}

First and foremost, one prominent explanation for leadership differences is based on the perception that women have less human capital in education, training, and work experience compared to men. In particular, women obtain undergraduate degrees at a higher rate than men do. Similarly, women earn professional and doctoral degrees at a rate greater or nearly equal to that of men. ${ }^{17}$ According to a survey of the American Bar Association (2013), women, for example, obtain 47.3\% of law degrees, but are significantly underrepresented in Federal Court positions with $24.1 \%$ and receive less salary than men. ${ }^{18}$ In fact, women often have less work experience than men do, which is caused by childcare and domestic duties. ${ }^{19} 20$

Furthermore, Carli, Eagly (2007) argue that domestic responsibilities cause substantial time pressure and women compensate time by giving up leisure time activities. ${ }^{21}$ However, given the fact that about $50 \%$ of all middle managers are female, this may provide evidence that women are being given the essential possibilities to receive the crucial management experience before being appointed for senior leadership positions. In contrast, other researches have emphasised the scarcity of highly trained female leaders as a contributing factor to the gender gap in the leader selection process, which is defined as a pipeline problem in the literature. There is a significant lack on women with adequate education and work

\footnotetext{
${ }^{14}$ Hoyt, C. L., Simon, S. (2016), Gender and Leadership. In: Northouse, P. G.: Leadership. Theory and Practice. Seventh Edition, United Kingdom, Sage Publications, p. 399.

${ }^{15}$ Gipson, A. N., Pfaff, D. L., Mendelsohn, D. B., Catenacci, L. T., Burke, W. W. (2017), Women and Leadership. Selection, Development, Leadership Style, and Performance. The Journal of Applied Behavioral Science, Vol. 53, Issue 1, p. 35.

${ }^{16}$ Yukl, G. (2013), Leadership in Organizations. England, Eighth Edition, Pearson, p. 358.

${ }^{17}$ Hoyt, C. L., Simon, S. (2016), Gender and Leadership. In: Northouse, P. G.: Leadership. Theory and Practice. Seventh Edition, United Kingdom, Sage Publications, p. 399.

${ }^{18}$ American Bar Association (2013), A current glance at women in the Law. https://www. americanbar.org/content/dam/aba/marketing/women/current_glance_statistics_ feb2013.authcheckdam.pdf (accessed on 25. February 2019).

${ }^{19}$ Hoyt, C. L., Simon, S. (2016), Gender and Leadership. In: Northouse, P. G.: Leadership. Theory and Practice. Seventh Edition, United Kingdom, Sage Publications, p. 400.

${ }^{20}$ Suter, L. E., Miller, H. P. (1973), Income Differences Between Men and Career Women. American Journal of Sociology, Vol. 78, Issue 4, pp. 962-963.

${ }^{21}$ Carli, L. L., Eagly, A. H. (2007), Through the Labyrinth. The truth about how women become leaders. Boston, Harvard Business School Publishing, p. 55.
} 
experience to choose from for senior leadership positions. ${ }^{22}$ Iwasaki, MacKay, Ristock (2004) explored the experiences of stress among both female and male managers. It could be researched that men and women experience stress differently. Although there were some similarities between men and women (e.g. a lack of sleep or financial stressors), female managers highlight that emotional stress was very draining, mostly because of the pressure to meet expectations and being responsible for others individuals compared to men. Female managers feel responsible for work both inside and outside their homes. Iwasaki, MacKay, Ristock (2004) further report that male managers were primarily focused on themselves and regarded other affairs as beyond their control and responsibility. Moreover, the study found that female leaders tend to talk more extensively and emotionally how their family-home lives became a source of stress compared to male managers. Following that, female managers experience a greater amount of stress from their family-home lives than male mangers. One explanation for this phenomenon is based on the argument that female managers are expected to perform substantial family and home responsibilities. ${ }^{23}$

In addition, McGuire (2002) performed an empirical research with more than 1,000 financial service employees and could identify that women are facing significant barriers in establishing informal networks. The study revealed that women tend to have jobs that limit their ability to form resourceful networks. Moreover, women were less likely than their male counterparts to have positions in which they make final decisions and interact with staff members outside of their work groups. Following that, male network members were more likely to control company resources than women were. $^{24}$ Similarly, Lyness, Heilman (2006) conducted a study and showed that the relationship between performance ratings and promotions was weaker for men than for women. The authors argue that male managers take more advantage of informal means than women for

${ }^{22}$ Gipson, A. N., Pfaff, D. L., Mendelsohn, D. B., Catenacci, L. T., Burke, W. W. (2017), Women and Leadership. Selection, Development, Leadership Style, and Performance. The Journal of Applied Behavioral Science, Vol. 53, Issue 1, p. 36.

${ }^{23}$ Iwasaki, Y., MacKay, K. J., Ristock, J. (2004), Gender-Based Analyses of Stress Among Professional Managers: An Exploratory Qualitative Study. International Journal of Stress Management. Vol. 11, Issue 1, p. 75.

${ }^{24}$ McGuire, G. M. (2002), Gender, Race, and the Shadow Structure: A Study of Informal Networks and Inequality in a Work Organization. Gender and Society, Vol. 16, Issue 3, p. 315. 
career advancement do. ${ }^{25}$ Taken together these findings, women are still facing significant hurdles from accessing top leadership positions. ${ }^{26}$

Gender and leadership effectiveness

After having briefly discussed the leadership gap from human capital perspective, the author puts emphasis on gender differences in leadership and its effectiveness in more detail substantiating with empirical research.

To begin with, Eagly, Johnson (1990) performed a meta-analysis to identify leadership style differences between men and women. Results show that against stereotypic expectations that women do not generally lead in a more interpersonal and men in more task-oriented manner. ${ }^{27} 28$ Surprisingly, research revealed that women tend to apply more democratic or participative leadership styles. ${ }^{29} 30$

Further research work conducted by Eagly, Johannesen-Schmidt, van Engen (2003) focusing on transformational, transactional, and laissez-faire leadership indicated that women tend to apply more transformational leadership than men. Similarly, the same is valid for transactional leadership. Women are more prone to offer rewards for appropriate performance to subordinates than men are. Besides, Eagly, Johannesen-Schmidt, van Engen (2003) suppose that less effective leadership styles such as laissez-faire behaviour were more common in men. Moreover, it could be researched that female leaders possess a wider range of different leadership behaviours than male leaders. In particular, this refers to transformational and contingent reward behaviours. ${ }^{31}$ Chin (2014) highlights that although

${ }^{25}$ Lyness, K. S., Heilman, M. E. (2006), When Fit Is Fundamental: Performance Evaluations and Promotions of Upper-Level Female and Male Managers. Journal of Applied Psychology, Vol. 91, Issue 4, p. 784.

${ }^{26}$ Gipson, A. N., Pfaff, D. L., Mendelsohn, D. B., Catenacci, L. T., Burke, W. W. (2017), Women and Leadership. Selection, Development, Leadership Style, and Performance. The Journal of Applied Behavioral Science, Vol. 53, Issue 1, p. 37.

${ }^{27}$ Eagly, A. H., Johnson, B. T. (1990), Gender and Leadership Style: A Meta-Analysis. Psychological Bulletin, Vol. 108, Issue 2, pp. 247-249.

${ }^{28}$ Hoyt, C. L., Simon, S. (2016), Gender and Leadership. In: Northouse, P. G.: Leadership. Theory and Practice. Seventh Edition, United Kingdom, Sage Publications, p. 402.

${ }^{29}$ Chin, J. L. (2014), Women and Leadership. In: Day, D. V.: The Oxford Handbook of Leadership and Organizations. New York, Oxford University Press, p. 738.

30 Trinidad, C., Normore, A. H. (2005), Leadership and gender: a dangerous liaison? Leadership \& Organization Development Journal, Vol. 26, Issue 7, p. 583.

${ }^{31}$ Eagly, A. H., Johannesen-Schmidt, M. C., van Engen, M. L. (2003), Transformational, Transactional, and Laissez-Faire Leadership Styles: A Meta-Analysis Comparing Women and Men. Psychological Bulletin, Vol. 129, Issue 4, pp. 586-587. 
these differences are small; the implications are encouraging because it identifies areas of strengths of female leaders. ${ }^{32}$

Regarding leadership effectiveness, Eagly, Karau, Makhijani (1995) found that female and male leaders do not distinguish in leadership effectiveness in general. Surprisingly, research revealed one robust gender difference in such a way that women and men were more effective in leadership roles that were congruent with their gender. For example, female leaders were less effective than men in military positions, but more effective than men in education, government, and social service organisations, as well as in positions where communal interpersonal skills are appreciated. Furthermore, women were less effective than their male counterparts when they supervised a higher number of male subordinates.

Taking these findings together, Eagly, Karau, Makhijani (1995) highlight that being "out of role" in gender-defined terms may cause a decline in leaders' perceived effectiveness. ${ }^{33} 34$

Research also focused on the presumed gender difference that women allocate less effort to work than men do with the argument that women have greater family responsibilities. The study by Bielby, Bielby (1988) showed that women tend to work at jobs that require slightly more effort. Compared to men with comparable domestic responsibilities market human capital, income, promotion possibilities, and job responsibilities women allocate significantly more effort to work activities compared to men. Despite greater household responsibilities, women must be able to draw on reserve of energy that is either not available to the typical male or, more realistically, that their male counterparts choose not to drawn upon. ${ }^{35}$

Moreover, Eagly, Karau (1991) performed a meta-analytic review on leader emergence and found out that men were more likely to emerge as leaders in groups than women were. Women were more attentive to interpersonal relationships and group harmony than men were. Besides, women were more likely to serve as social facilitators instead of leaders. The authors assume that women apparently have a greater chance of receiving a leadership position under certain circumstances that include,

${ }^{32}$ Chin, J. L. (2014), Women and Leadership. In: Day, D. V.: The Oxford Handbook of Leadership and Organizations. New York, Oxford University Press, p. 738.

${ }^{33}$ Hoyt, C. L., Simon, S. (2016), Gender and Leadership. In: Northouse, P. G.: Leadership. Theory and Practice. Seventh Edition, United Kingdom, Sage Publications, pp. 402-403.

${ }^{34}$ Eagly, A. H., Karau, S. J., Makhijani, M. G. (1995), Gender and the Effectiveness of Leaders: A Meta-Analysis. Psychological Bulletin, Vol. 117, Issue 1, pp. 137-141.

${ }^{35}$ Bielby, D. D., Bielby, W. T. (1988), She Works Hard for the Money: Household Responsibilities and the Allocation of Work Effort. American Journal of Sociology, Vol. 93, Issue 5, pp. 1055-1056. 
for example, social tasks. ${ }^{36}$ In contrast, Kent, Moss (1994) performed an empirical study and found that women were slightly more likely to emerge as leaders than men were. ${ }^{37} \mathrm{~A}$ further gender difference researched by Babcock, Laschever (2003) indicated that women are much less likely to see benefits and necessity for asking for what they really want. ${ }^{38}$

Furthermore, research by Ryan, Haslam (2005) showed that women were more likely to be appointed to leadership positions in circumstances of general financial downturns. ${ }^{39}$ In particular, Haslam, Ryan (2008) investigated the circumstances surrounding the appointment of directors in companies in Britain and could reveal that women are overrepresented in precarious leadership positions. This phenomenon is called "the glass cliff". In particular, for companies that placed men to their company boards, share price performance remained stable, both before and after the appointment. In contrast, in times of stock market downturns, companies that appointed female leaders had experienced poor financial performance. Derived from that, men and women were positioned to directorships under very different conditions. ${ }^{40}$

In addition, the study by Nielsen, Huse (2010) makes several contributions to current discussions about the role of female directors on corporate boards. To begin with, the authors found that the impact of women on corporate boards depends on the nature of task executed. In general, no overall differences were detected between the behaviour of female and male managers, but it could be researched that women directors' leadership varies slightly compared to men in specific circumstances. In particular, the ratio of female directors has a positive direct relationship with board strategic control but no direct relationship with board operational control. Thus, these findings indicate that female directors do not carry out operational control tasks better or worse compared to male managers, they contribute certain benefits to the board decisionmaking when it comes to strategic tasks. It is further argued that women

${ }^{36}$ Eagly, A. H., Karau, S. J. (1991), Gender and the Emergence of Leaders - A MetaAnalysis. Journal of Personality and Social Psychology, Vol. 60, Issue 5, p. 705.

${ }^{37}$ Kent, R. L., Moss, S. E. (1994), Effects of sex and gender role on leader emergence. Academy of Management Journal, Vol. 37, Issue 5, p. 1343.

${ }^{38}$ Babcock, L., Laschever, S. (2003), Women don't ask. Negotiation and the Gender Divide. Princeton, Princeton University Press, p. 20.

${ }^{39}$ Ryan, M. K., Haslam, A. S. (2005), The Glass Cliff: Evidence that Women are OverRepresented in Precarious Leadership Positions. British Journal of Management, Vol. 16, Issue 2, pp. 86-87.

${ }^{40}$ Haslam, A. S., Ryan, M. K. (2008), The road to the glass cliff: Differences in the perceived suitability of men and women for leadership positions in succeeding and failing organizations. The Leadership Quarterly, Vol. 19, Issue 5, pp. 530-531. 
have a wider sensitivity towards colleagues and their consideration of the interests and perspectives of all included parties increases board oversight of company strategy. These findings contribute the understanding why it is tricky to establish a direct relationship between board gender composition and company performance. ${ }^{41}$

Similarly, Adams, Ferreira (2009) conducted a research to identify whether governance characteristics of boards that are more diverse are different from those that are less diverse. It was revealed that women attend more meetings and are more likely to be assigned to monitoringrelated committees compared to their male counterparts. In case women also participated actively at board and monitoring committee meetings, the monitoring intensity of the total board increased. ${ }^{42}{ }^{43}$ However, Melero (2011) conducted further research to reveal how workplace management teams with a higher proportion of women tend to use different peoplemanagement practices. The study found that women tend to show more individualised consideration of employees than men do. The findings further suggest that these management teams seem to develop more interpersonal communication channels with staff members and foster their participation in decision-making processes. From the theoretical framework perspective, the findings highlight the assumption that the influence of women in the overall selection of workplace management practices raises with their relative presence in the management team. ${ }^{44}$

In addition, Post (2015) performed an empirical research to understand to what extend and in what contexts female leaders may be beneficial for teams. In particular, the study explored how team leader gender relates to team cohesion, cooperative learning, and participative communication. Results show that teams may benefit from female group leaders to develop cohesion, cooperative learning, and participative communication when team coordination requirements are higher, such as when teams are more functionally diverse, larger, or geographically dispersed. As diversity raises, teams led by women show a higher cohesion compared with teams led by men. In case team size enhances, female-led teams respond with more

${ }^{41}$ Nielsen, S., Huse, M. (2010), The Contribution of Women on Boards of Directors. Going beyond the Surface. Corporate Governance: An International Review, Vol. 18, Issue 2, p. 143.

${ }^{42}$ Adams, R., Ferreira, D. (2009), Women in the boardroom and their impact on governance and performance. Journal of Financial Economics, Vol. 94, Issue 2, pp. 295; 301.

${ }^{43}$ Gipson, A. N., Pfaff, D. L., Mendelsohn, D. B., Catenacci, L. T., Burke, W. W. (2017), Women and Leadership. Selection, Development, Leadership Style, and Performance. The Journal of Applied Behavioral Science, Vol. 53, Issue 1, pp. 53-54.

${ }^{44}$ Melero, E. (2011), Are workplaces with many women in management run differently? Journal of Business Research. Vol. 64, Issue 4, pp. 390-391. 
cohesion, co-operative learning, and participative learning compared with similar teams with male superiors. Finally, among geographically dispersed teams, those teams with female leaders show more cooperative learning and participative communication than those with male managers. ${ }^{45}$

Considering leadership effectiveness from the financial outcome perspective, Jalbert, Jalbert, Furumo (2013) conducted a study to determine if gender affects financial company performance. In this respect, the authors collected data from Forbes magazine and Compustat including 6,305 firm year observations covering a time period from 1997 until 2006. The results indicate that gender has significantly explanatory power for the Return on Investment, Price to Earnings Ratio, Return on Assets, Sales Growth and Institutional Ownership. The results highlight that female Chief Executives Officers lead companies differently and are recognised differently by financial markets. ${ }^{46}$ Besides, Davis et al. (2010) performed a very similar study but with focus on CEO gender on market orientation and performance among small and medium-sized companies. According to the results, no significant relationship was found between CEO genders and financial and market performance in small and medium-sized companies. Although there are some indications for a marginal higher performance among female-led companies, the research results are not significant, indicating that gender does not affect company performance. Furthermore, it could be researched that female leaders put much more emphasis on market orientation compared to men. ${ }^{47}$

A further stream of scholars researched how board diversity affects firm value. Results show that women or minorities on the board positively and significantly affect the firm value. ${ }^{48}$ In contrast, Darmadi (2013) performed a similar research in Indonesia to examine the relationship between gender diversity on the management board and the financial performance of listed companies. The author applied a cross-sectional regression analysis and found that the representation of women on management boards negatively and significantly affects firm performance. Based on

45 Post, C. (2015), When is female leadership an advantage? Coordination requirements, team cohesion, and team interaction norms. Journal of Organizational Behavior, Vol. 36, Issue 8, pp. 1153; 1166-1167.

${ }^{46}$ Jalbert, T., Jalbert, M., Furumo, K. (2013), The Relationship Between CEO Gender, Financial Performance, And Financial Management. Journal of Business \& Economics Research, Vol. 11, Issue 1, p. 32.

${ }^{47}$ Davis, P. S., Babakus, E., Englis, P. D., Pett, T. (2010), The Influence of CEO Gender on Market Orientation and Performance in Service Small and Medium-Sized Service Businesses. Journal of Small Business Management, Vol. 48, Issue 4, p. 488.

${ }^{48}$ Carter, D. A., Simkins, B. J., Simpson, G. W. (2003), Corporate Governance, Board Diversity, and Firm Value. The Financial Review, Vol. 38, Issue 1, p. 51. 
that, a higher proportion of female leaders tends to lower the company performance. The authors further stress that a higher proportion of women on management boards is more likely to occur in small companies, which are often family-controlled. ${ }^{49}$ Thus, it can be concluded that research offers mixed results how women on corporate boards increase the financial performance of companies. ${ }^{50}$

Next, research started examining the impact of female leaders throughout the organisation and firm financial performance. In this respect, Dwyer, Richard, Chadwick (2003) could identify a positive relationship between gender diversity, growth orientation and performance. This is argued that potential benefits of gender diversity such as new insights, perspectives, creativity, and experience seem to boost expansion into new markets. ${ }^{51}$

\section{Gender and stereotypes}

Moreover, one further explanation of leadership gaps is grounded on stereotyped expectations (prejudice). ${ }^{52}$ Biased beliefs about certain skills and behaviours essential for being an effective leader are prominent reasons for sex-based discrimination. ${ }^{53}$ Stroebe, Chester (1989) define a stereotype as a set of beliefs about the personal attributes of a group of individuals. ${ }^{54}$ Eagly, Karau (2002) describe stereotypes as consensual beliefs about the attributes of men and women. ${ }^{55}$ Thus, stereotypes are at the heart of numerous theories and frameworks trying to explore gender

${ }^{49}$ Darmadi, S. (2013): Do women in top management affect firm performance? Evidence from Indonesia. Corporate Governance: The international journal of business in society, Vol. 13, Issue 3, p. 300.

${ }^{50}$ Gipson, A. N., Pfaff, D. L., Mendelsohn, D. B., Catenacci, L. T., Burke, W. W. (2017), Women and Leadership. Selection, Development, Leadership Style, and Performance. The Journal of Applied Behavioral Science, Vol. 53, Issue 1, p. 53.

${ }^{51}$ Dwyer, S., Richard, O. C., Chadwick, K. (2003), Gender diversity in management and firm performance: the influence of growth orientation and organizational culture. Journal of Business Research, Vol. 56, Issue 12, p. 1016.

${ }^{52}$ Hoyt, C. L., Simon, S. (2016), Gender and Leadership. In: Northouse, P. G.: Leadership. Theory and Practice. Seventh Edition, United Kingdom, Sage Publications, p. 404.

${ }^{53}$ Yukl, G. (2013), Leadership in Organizations. Eighth Edition, England, Pearson Publications, p. 359.

${ }^{54}$ Stroebe, W., Chester, I. A. (1989), Stereotype, Prejudice, and Discrimination. In: BarTal, D., Graumann, C. F., Kruglanski, A. W., Stroebe, W. (Ed.), Stereotyping and Prejudice. Changing Concepts. New York, Springer Science+Business Media, p. 5.

${ }^{55}$ Eagly, A. H., Karau, S. J. (2002), Role Congruity Theory of Prejudice Toward Female Leaders. Psychological Review, Vol. 109, Issue 3, p. 574. 
gaps in leadership selection rates. ${ }^{56}$ According to the role congruity theory, women are positively associated with roles that correspond to typical social roles. In this respect, Eagly, Karau (2002) highlight some disadvantages for women. It assumes that women have less leadership qualities than men do in particular situations. ${ }^{57}$ Moreover, women are confronted with crosspressures as leaders should be masculine but as woman, they should not be too manly. This causes the perception that women seem to be less qualified for higher leadership positions than men do. ${ }^{58}$ In particular, Burgess, Borgida (1999) distinguish between descriptive and prescriptive components of gender stereotypes. Descriptive aspects of gender stereotypes lead to perceptions that women are not suitable for maledominated tasks and jobs, which results in biases against hiring women for certain types of occupations. In contrast, prescriptive components of gender stereotypes may cause devaluations or even harassments of women who violate gender role prescriptions. The authors further stress that women who behave, for example in an autocratic manner or who occupy traditional male occupations are likely to be negatively sanctioned. These negative evaluations usually occur on communal or on interpersonal levels rather than on competency dimensions. ${ }^{59}$

Similarly, Heilman's lack of fit model postulates that results that come from discriminatory against women are grounded on a mismatch between the attributes that women are thought to possess and the attributes seen as essential for success in male-dominated positions and fields. This incongruity embodies the basis of negative expectations about women's performance to bias the processing of information and, consequently, facilitates discriminatory behaviour. Again, central to this theory is a consideration of gender stereotypes - in particular, preconceptions in view of what men and women ought to be. ${ }^{60}$

In addition, a study conducted by Forsyth, Heiney, Wright (1997) researched role-incongruence in small groups led by women who applied

${ }^{56}$ Gipson, A. N., Pfaff, D. L., Mendelsohn, D. B., Catenacci, L. T., Burke, W. W. (2017), Women and Leadership. Selection, Development, Leadership Style, and Performance. The Journal of Applied Behavioral Science, Vol. 53, Issue 1, p. 35.

${ }^{57}$ Eagly, A. H., Karau, S. J. (2002), Role Congruity Theory of Prejudice Toward Female Leaders. Psychological Review, Vol. 109, Issue 3, pp. 588-591.

${ }^{58}$ Hoyt, C. L., Simon, S. (2016), Gender and Leadership. In: Northouse, Peter G.: Leadership. Theory and Practice. Seventh Edition, p. 405.

${ }^{59}$ Burgess, D., Borgida, E. (1999), Who women are, who women should be. Descriptive and Prescriptive Gender Stereotyping in Sex Discrimination. Psychology, Public Policy, and Law, Vol. 5, Issue 3, pp. 676-677.

${ }^{60}$ Heilman, M. E., Caleo, S. (2018), Combatting gender discrimination. A lack of fit framework. Group Processes \& Intergroup Relations, Vol. 21, Issue 5, p. 726. 
relationship- or task-oriented leadership styles. It was revealed that conservative group participants reacted more negatively to female taskoriented leaders and rated the female leader lower regarding collegiality. In contrast, group participants with a liberal attitude towards women responded positively to both leadership styles. ${ }^{61}$

Moreover, the think-manager - think-male paradigm fostered sex role stereotypes. In particular, Schein's et al. (1996) research revealed that females and males perceive that successful middle managers possess characteristics and attitudes more commonly ascribed by men in general than to women. The study was repeated several times with Chinese and Japanese, as well as with British, German and US students. Although the participants had different historical, political and cultural backgrounds, the view of women as less likely than men to possess requisite management characteristics is a commonly held belief among male students around the globe. ${ }^{62}$

Together these theories have significantly affected the work that has been carried out so far in order to improve the understanding how gender bias and prejudice influence the perception and evaluation of female individuals aspiring to leadership positions. ${ }^{63}$

In general, the number of female leaders who successfully navigate this leadership labyrinth is improving. For Hoyt, Simon (2016), changes in the organisation are taking place and making it easier for women to hold top leadership positions. The company cultures are changing as several companies value flexible working and diversity in their top management levels. Moreover, assigning more female leaders to high-visibility positions and developing effective and supportive mentoring relationships for women are key approaches for lowering the leadership gap. ${ }^{64} 65$ The following Figure 2 summarises and illustrates different strategies how women can promote leadership effectiveness.

${ }^{61}$ Forsyth, D., Heiney, M. M., Wright, S. S. (1997), Biases in Appraisals of Women Leaders. Group Dynamics: Theory, Research, and Practice, Vol. 1, Issue 1, pp. 98; 101.

${ }^{62}$ Schein, V. E., Mueller, R., Lituchy, T., Liu, J. (1996), Think Manager - Think Male: A Global Phenomenon? Journal of Organizational Behavior, Vol. 17, Issue 1, pp. 33-34; 39.

${ }^{63}$ Gipson, A. N., Pfaff, D. L., Mendelsohn, D. B., Catenacci, L. T., Burke, W. W. (2017), Women and Leadership. Selection, Development, Leadership Style, and Performance. The Journal of Applied Behavioral Science, Vol. 53, Issue 1, p. 35.

${ }^{64}$ Hoyt, C. L., Simon, S. (2016), Gender and Leadership. In: Northouse, Peter G.: Leadership. Theory and Practice. Seventh Edition, pp. 406-407.

${ }^{65}$ Ragins, B. R., Townsend, B., Mattis, M. (1998), Gender gap in the executive suite: CEOs and female executives report on breaking the glass ceiling. Academy of Management Executives, Vol. 12, Issue 1, p. 40. 


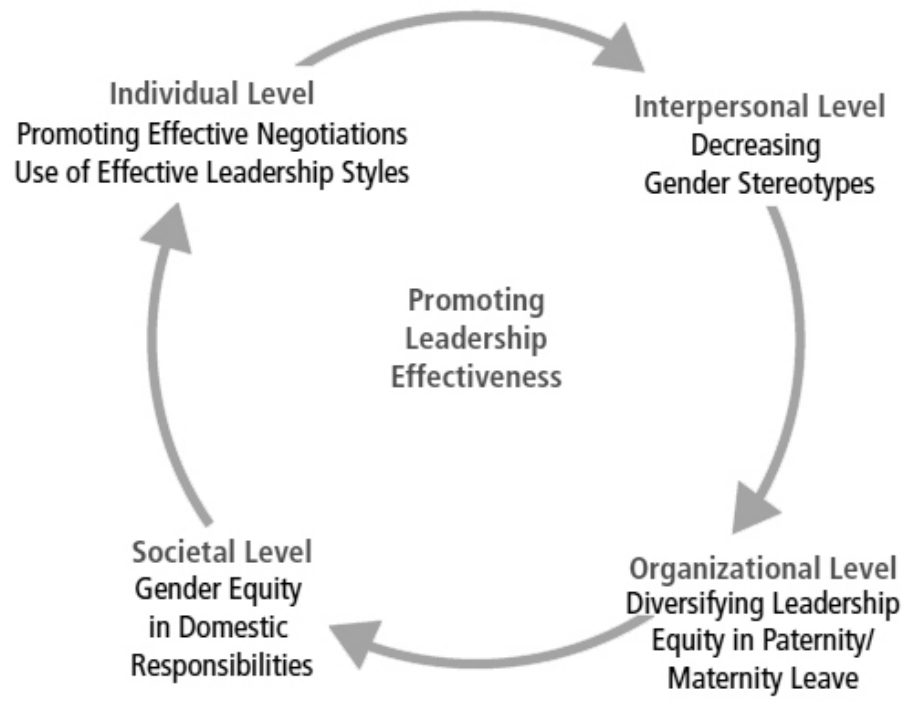

Source: Hoyt, Simon, 2016, p. 407.

Figure 2. Promoting Leadership Effectiveness

\section{Conclusion}

To conclude, the understanding for leadership and gender is crucial in several ways. To begin with, scholars started to explore if differences between men and women exist in terms of human capital. In general, figures show that women tend to be more educated than men are. In fact, women have less work experience than men, which can be traced back to domestic duties, as well as to childcare responsibilities. However, given the fact that about half of the middle managers are women this may provide evidence that women collect sufficient work experience before being appointed for senior leadership positions.

To improve the understanding of gender and leadership effectiveness substantial research has been performed. In general, research showed that leadership between men and women varies slightly. In particular, women tend to apply more democratic, participative, as well as transformational leadership styles compared to men. Furthermore, female CEO's contribute significantly to decision-making and show more cohesion, co-operative learning and participative communication compared to men. Evaluating leadership and gender from the financial point of view, research results vary significantly in terms of company size and market performance and 
offer mixed support for management science. Research showed that women are more likely to be selected for leadership positions in times of company crises. This phenomenon is called the glass cliff. Surprisingly, research found a gender difference in such a way that women and men were more effective in leadership roles that were congruent with their gender. For example, female leaders were less effective than men in military positions were, but more effective than men in education were, or social service organisations were. Moreover, the think-manager - think-male paradigm from Schein contributed to sex role stereotypes. In particular, research revealed that men and women perceive that successful middle managers possess characteristics, attitudes and temperaments more commonly ascribed by men than to women. The studies from Schein et al. were repeated several times, but showed a coherent result. Furthermore, Heilman's lack of fit model also deals with discriminatory against women, which is grounded on a mismatch between the attributes that women are perceived to possess and the attributes seen as essential for success in male-dominated positions and fields.

\section{REFERENCES}

Adams, R., Ferreira, D. (2009). Women in the boardroom and their impact on governance and performance. Journal of Financial Economics, Vol. 94, Issue 2, pp. 291-309, https://doi.org/10.1016/j.jfineco.2008.10.007.

American Bar Association (2013). A current glance at women in the Law. https://www. americanbar.org/content/dam/aba/marketing/women/current_glance_statistics_ feb2013.authcheckdam.pdf (accessed on 03. February 2019).

Babcock, L., Laschever, S. (2003). Women don't ask. Negotiation and the Gender Divide. Princeton, Princeton University Press.

Bielby, D. D., Bielby, W. T. (1988). She Works Hard for the Money: Household Responsibilities and the Allocation of Work Effort. American Journal of Sociology, Vol. 93, Issue 5, pp. 1031-1059.

Burgess, D., Borgida, E. (1999). Who women are, who women should be. Descriptive and Prescriptive Gender Stereotyping in Sex Discrimination. Psychology, Public Policy, and Law, Vol. 5, Issue 3, pp. 665-692, http://dx.doi.org/10.1037/10768971.5.3.665.

Carli, L. L., Eagly, A. H. (2011). Gender and Leadership. In: Bryman, A., Collinson, D., Grint, K., Jackson, B., Uhl-Bien, M. The Sage Handbook of Leadership, London, Sage Publications, pp. 103-117.

Carli, L. L., Eagly, A. H. (2007). Through the Labyrinth. The truth about how women become leaders. Boston, Harvard Business School Publishing.

Carter, D. A., Simkins, B. J., Simpson, G. W. (2003). Corporate Governance, Board Diversity, and Firm Value. The Financial Review, Vol. 38, Issue 1, pp. 33-53, https:// doi.org/10.1111/1540-6288.00034. 
Catalyst (2018). Pyramid: Women in S\&P 500 companies. https://www.catalyst.org/ research/women-in-sp-500-companies (accessed on 22. February 2019).

Center for American Women and Politics (2016). Women in Elective Office 2016. http:// www.cawp.rutgers.edu/women-elective-office-2016 (accessed on 23. February 2019).

Chin, J. L. (2014). Women and Leadership. In: Day, D. V.: The Oxford Handbook of Leadership and Organizations. New York, Oxford University Press, pp. 733-753.

Darmadi, S. (2013). Do women in top management affect firm performance? Evidence from Indonesia. Corporate Governance: The international journal of business in society, Vol. 13, Issue 3, pp. 288-304, https://doi.org/10.1108/CG-12-2010-0096.

Davis, P. S., Babakus, E., Englis, P. D., Pett, T. (2010). The Influence of CEO Gender on Market Orientation and Performance in Service Small and Medium-Sized Service Businesses. Journal of Small Business Management, Vol. 48, Issue 4, pp. 475-496, https://doi.org/10.1111/j.1540-627X.2010.00305.x.

Dwyer, S., Richard, O. C., Chadwick, K. (2003). Gender diversity in management and firm performance: the influence of growth orientation and organizational culture. Journal of Business Research, Vol. 56, Issue 12, pp. 1009-1019, https://doi. org/10.1016/S0148-2963(01)00329-0.

Eagly, A. H., Johannesen-Schmidt, M. C., van Engen, M. L. (2003). Transformational, Transactional, and Laissez-Faire Leadership Styles: A Meta-Analysis Comparing Women and Men. Psychological Bulletin, Vol. 129, Issue 4, pp. 569-591, http:// dx.doi.org/10.1037/0033-2909.129.4.569.

Eagly, A. H., Johnson, B. T. (1990). Gender and Leadership Style: A Meta-Analysis. Psychological Bulletin, Vol. 108, Issue 2, pp. 233-256, http://dx.doi.org/10.1037/00332909.108.2.233.

Eagly, A. H., Karau, S. J. (1991). Gender and the Emergence of Leaders - A MetaAnalysis. Journal of Personality and Social Psychology, Vol. 60, Issue 5, pp. 685-710, http://dx.doi.org/10.1037/0022-3514.60.5.685.

Eagly, A. H., Karau, S. J. (2002). Role Congruity Theory of Prejudice Toward Female Leaders. Psychological Review, Vol. 109, Issue 3, pp. 573-598, http://dx.doi. org/10.1037/0033-295X.109.3.573.

Eagly, A. H., Karau, S. J., Makhijani, M. G. (1995). Gender and the Effectiveness of Leaders: A Meta-Analysis. Psychological Bulletin, Vol. 117, Issue 1, pp. 125-145, http://dx.doi.org/10.1037/0033-2909.117.1.125.

Eklund, K. E., Barry, E. S., Grunberg, N. E. (2017). Gender and Leadership. Intech open science open minds, pp. 129-150, http://dx.doi.org/10.5772/65457.

Forsyth, D., Heiney, M. M., Wright, S. S. (1997). Biases in Appraisals of Women Leaders. Group Dynamics: Theory, Research, and Practice, Vol. 1, Issue 1, pp. 98-103, http:// dx.doi.org/10.1037/1089-2699.1.1.98.

Gipson, A. N., Pfaff, D. L., Mendelsohn, D. B., Catenacci, L. T., Burke, W. W. (2017). Women and Leadership. Selection, Development, Leadership Style, and Performance. The Journal of Applied Behavioral Science, Vol. 53, Issue 1, pp. 32-65, https://doi.org/10.1177/0021886316687247. 
Grant Thornton (2016). Women in business. Turning promise into practice - Grand Thornton International Business Report 2016. https:/www.grantthornton.global/globalassets/ wib_turning_promise_into_practice.pdf (accessed on 23. February 2019).

Haslam, A. S., Ryan, M. K. (2008). The road to the glass cliff: Differences in the perceived suitability of men and women for leadership positions in succeeding and failing organizations. The Leadership Quarterly, Vol. 19, Issue 5, pp. 530-546, https://doi. org/10.1016/j.leaqua.2008.07.011.

Heilman, M. E., Caleo, S. (2018). Combatting gender discrimination. A lack of fit framework. Group Processes \& Intergroup Relations, Vol. 21, Issue 5, pp. 725-744, https://doi.org/10.1177/1368430218761587.

Hoyt, C. L., Simon, S. (2016). Gender and Leadership. In: Northouse, Peter G.: Leadership. Theory and Practice. Seventh Edition, California, Sage Publications, pp. 397-426.

Iwasaki, Y., MacKay, K. J., Ristock, J. (2004). Gender-Based Analyses of Stress Among Professional Managers: An Exploratory Qualitative Study. International Journal of Stress Management. Vol. 11, Issue 1, pp. 56-79, http://dx.doi.org/10.1037/10725245.11.1.56.

Jalbert, T., Jalbert, M., Furumo, K. (2013). The Relationship Between CEO Gender, Financial Performance, And Financial Management. Journal of Business \& Economics Research, Vol. 11, Issue 1, pp. 25-34.

Kent, R. L., Moss, S. E. (1994). Effects of sex and gender role on leader emergence. Academy of Management Journal, Vol. 37, Issue 5, pp. 1335-1346, http://dx.doi. org/10.2307/256675.

Knoke, D., Ishio, Y. (1998). The Gender Gap in Company Job Training. Work and occupations, Vol. 25, Issue 2, pp. 141-167, https://doi.org/10.1177/07308884980 25002002.

Lyness, K. S., Heilman, M. E. (2006). When Fit Is Fundamental: Performance Evaluations and Promotions of Upper-Level Female and Male Managers. Journal of Applied Psychology, Vol. 91, Issue 4, pp. 777-785, http://dx.doi.org/10.1037/00219010.91.4.777.

McGuire, G. M. (2002). Gender, Race, and the Shadow Structure: A Study of Informal Networks and Inequality in a Work Organization. Gender and Society, Vol. 16, Issue 3, pp. 303-322, https://doi.org/10.1177/0891243202016003003.

Melero, E. (2011). Are workplaces with many women in management run differently? Journal of Business Research. Vol. 64, Issue 4, pp. 385-393, https://doi.org/10.1016/j. jbusres.2010.01.009.

Nielsen, S., Huse, M. (2010). The Contribution of Women on Boards of Directors. Going beyond the Surface. Corporate Governance: An International Review, Vol. 18, Issue 2, pp. 136-148, https://doi.org/10.1111/j.1467-8683.2010.00784.x.

Paustian-Underdahl, S. C., Walker, L. S., Woehr, D. J. (2014). Gender and Perceptions of Leadership Effectiveness: A Meta-Analysis of Contextual Moderators. Journal of Applied Psychology, Vol. 99, Issue 6, pp. 1129-1145, http://dx.doi.org/10.1037/ a0036751. 
Post, C. (2015). When is female leadership an advantage? Coordination requirements, team cohesion, and team interaction norms. Journal of Organizational Behavior, Vol. 36, Issue 8, pp. 1153-1175, https://doi.org/10.1002/job.2031.

Powell, G. N., Graves, L. M. (2003). Women and Men in Management. 3rd Edition, California, Sage Publications.

Ragins, B. R., Townsend, B., Mattis, M. (1998). Gender gap in the executive suite: CEOs and female executives report on breaking the glass ceiling. Academy of Management Executives, Vol. 12, Issue 1, pp. 28-42.

Ryan, M. K., Haslam, A. S. (2005). The Glass Cliff: Evidence that Women are OverRepresented in Precarious Leadership Positions. British Journal of Management, Vol. 16, Issue 2, pp. 81-90, https://doi.org/10.1111/j.1467-8551.2005.00433.x.

Schein, V. E., Mueller, R., Lituchy, T., Liu, J. (1996). Think Manager - Think Male: A Global Phenomenon? Journal of Organizational Behavior, Vol. 17, Issue 1, pp. 33-41, https:// doi.org/10.1002/(SICI)10991379(199601)17:1<33::AID-JOB778>3.0.CO;2-F.

Stroebe, W., Chester, I. A. (1989). Stereotype, Prejudice, and Discrimination. In: Bar-Tal, D., Graumann, C. F., Kruglanski, A. W., Stroebe, W. (Ed.), Stereotyping and Prejudice. Changing Concepts. New York, Springer Science+Business Media, pp. 3-34.

Suter, L. E., Miller, H. P. (1973). Income Differences Between Men and Career Women. American Journal of Sociology, Vol. 78, Issue 4, pp. 962-974, https://www.jstor.org/ stable/2776614.

Trinidad, C., Normore, A. H. (2005). Leadership and gender: a dangerous liaison? Leadership \& Organization Development Journal, Vol. 26, Issue 7, pp. 574-590, https:// doi.org/10.1108/01437730510624601.

Warner, J., Corley, D. (2017). The Women's Leadership Gap. Women's Leadership by the Numbers. Center for American Progress, p. 1, https://cdn.americanprogress.org/ content/uploads/2017/05/21145352/WomenLeadershipGap2017-factsheet1.pdf (accessed on 22. February 2019).

Wright, P. (2011). Women and leadership style. Group, Vol. 35, Issue 3, pp. 247-253, https://www.jstor.org/stable/41719326.

Yukl, G. (2013). Leadership in Organizations. Eighth Edition, England, Pearson. 